Work Papers of the Summer

Institute of Linguistics, University

of North Dakota Session

\title{
The implications of language documentation for an endangered but vibrant language community: A historical perspective
}

Stephen A. Marlett

SIL-UND

How does access to this work benefit you? Let us know!

Follow this and additional works at: https://commons.und.edu/sil-work-papers

Part of the Linguistics Commons

\footnotetext{
Recommended Citation

Marlett, Stephen A. (2008) "The implications of language documentation for an endangered but vibrant language community: A historical perspective," Work Papers of the Summer Institute of Linguistics, University of North Dakota Session: Vol. 49, Article 1.

DOI: 10.31356/silwp.vol49.01

Available at: https://commons.und.edu/sil-work-papers/vol49/iss1/1

This Article is brought to you for free and open access by UND Scholarly Commons. It has been accepted for inclusion in Work Papers of the Summer Institute of Linguistics, University of North Dakota Session by an authorized editor of UND Scholarly Commons. For more information, please contact und.commons@library.und.edu.
} 


\title{
The implications of language documentation for an endangered but vibrant language community: a historical perspective*
}

\author{
Stephen A. Marlett \\ SIL International and University of North Dakota
}

\begin{abstract}
Documentation of an endangered language may be a short project that is carried out with urgency and with primarily academic benefits because the speakers are not passing on the language to others. This paper presents historical perspective on a quite different kind of situation. The documentation of the Seri language has taken place over a considerable period of time and with goals that were primarily community-focused. It documents some of the challenges that have been present during those years and also the benefits of that documentation that are just now beginning to be felt by the speakers of that language.
\end{abstract}

\section{The Seri people and their language}

The name SERI has for hundreds of years evoked reactions of fear, pity, curiosity, and sometimes loathing by outsiders. One of the earliest references to this group indicates that the term Seri was applied by the Spanish to the ,wild peoples "e who lived along the coast of Mexico and who had not been properly subjugated neither to the will of the Spanish Crown nor of the Church (Spicer 1962: 105). They were described as being wild in part because of their nomadic lifestyle (without proper housing), and their disinterest in agriculture and a sedentary mission life. Their language was characterized as being ,extremely difficult (Sheridan 1999: 23). The first clearly-recorded encounter between the Spanish and the Seris, in 1662, was a battle in which reportedly two or three hundred Seri men and women fought to the last person, leaving only their children alive to be taken into custody and resettled elsewhere by the invaders (Spicer 1962: 105). It was a not very auspicious beginning.

It is not known when or how the Seris (the comcaac, as they name themselves) came to be located in northwestern Mexico, occupying parts of the mainland, some islands in the Gulf of California (Bowen 1983), and parts of the Baja peninsula Bowen (Herrera Casanova, to appear). The scientific data is very slim. Perhaps the Seris were pushed back into this area by the incursions of the Uto-Aztecans - those who would later be called Yaquis, Mayos, Ópatas, Eudeves, Pimas, and Papagos. Perhaps, instead, the Seris arrived later and established their place in the mid-Gulf region by taking some of the territory occupied by Uto-Aztecans. There is no archeological evidence of overlap in either direction, however. Whatever the story, it happened a very long time ago. This has been their home for many centuries and it is an area which in the modern era hardly a single one of them has chosen to leave. Outsiders talk of the

\footnotetext{
* This paper is an expanded version of the paper which was presented at the $75^{\text {th }}$ anniversary conference of SOAS (London) and which appeared in the proceedings (Marlett 2007c). I gratefully acknowledge the support of the National Endowment of the Humanities for the work on the documentation of the grammar in 2007 through the Documenting Endangered Languages Program (FN-50007-06). My sincere thanks to those who read preliminary versions and made helpful suggestions: Tom Headland, Kathy Lehardy, Cathy Marlett, Becky Moser, and Cindy Williams.
}

Work Papers of the Summer Institute of Linguistics, University of North Dakota Session, vol. 49 (2005-8)

http://arts-sciences.und.edu/summer-institute-of-linguistics/work-papers/_files/docs/2008-marlett.pdf

Copyright (C) 2008 by SIL International 
dry and inhospitable desert, of the rocks and sand, of the heat, of the difficulties. The Seris do not talk this way at all; they only talk about their home and of the bounty that the sea and the hehe án,place of the plantse (what we call the desert) have provided to them.

During the centuries before the Spanish contact, there must have been interaction between the Seris and other groups in the area, but the evidence of that contact is very small. If there were other linguistic groups that were related to the Seris, we don't know anything about them. Attempts to link the Seris to other groups in California and Mexico - the Yumans, the Salinans, and the Chontal, among others have been unconvincing. After a century of hypothesizing a connection with the so-called Hokan languages, the evidence today is hardly more than the meager sampling presented during the last century; the hypothesis has not held up to closer public scrutiny (Campbell 1997, Marlett, in press a; Marlett, in press $b$ ). The contact between the Seris and the neighboring Uto-Aztecan groups has produced a relatively small amount of detectable linguistic borrowing (Marlett 2007a), although there is more evidence of relatively recent cultural influence (probably during the period between 1700 and 1900) (Bowen 1983: 232).

The four and a half centuries of contact with Europeans and later with non-Indian Mexicans have proved to be extremely difficult. Number-wise, the Seris were reduced from an estimated 3,000 people in 1692 to 160 in 1941 (Bowen 1983: 234). This was due in part to measles and probably influenza as well as other European diseases, high infant mortality, deportations, various skirmishes, outright massacres, tuberculosis and alcoholism. Many observers over the years have announced the impending demise of the Seri people, sometimes with regret and sometimes without remorse (see Coolidge and Coolidge 1939 and Corey 1922: 469 among many).

Fortunately, a number of factors have led to a dramatic turn-around of the situation, beginning around the middle of the twentieth century. These factors include:

(a) changes in Mexican government policy, beginning perhaps as early as $1930^{\circ e} \mathrm{~s}$ with President Lázaro Cárdenase s policies that promoted the well-being of the indigenous populations; the creation of the Instituto Nacional Indigenista in 1948 (which early on explicitly recognized the great danger in which the Seri people were).

(b) a geographical buffer (mountains, desert) which resulted in the lack of continued intrusions by ranchers on the central Seri area;

(c) friendship with certain local Mexicans (e.g., Roberto Thomson);

(d) economic help (fishing cooperative), visits by American tourists who had greater disposable income and who found the Seris somewhat exotic;

(e) medical help (measles inoculations, births); establishment of modest clinics; access to hospitals because of greater personal income;

(f) reduction in alcoholism through the influence of a Mexican church that strongly opposes the use of alcohol;

(g) interest by outsiders in the people - including visiting scientists, tourists (both Mexican and American), a resident (American) anthropology student, humanitarian groups (Society of Friends) and by resident non-Seris (schoolteachers Leo Sandoval and María Reyes, storekeeper Óscar Topete).

(h) interest in the people, language and culture by resident Bible-translator-linguists (Edward and Mary Moser) who, as SIL members working within the guidelines of the Mexican secretariat of education, developed a written form of the language that continues to be in use today.

In later decades, other factors would continue to benefit the Seri people: an increased consciousness by the general Mexican population of their indigenous heritage, sensitivity to Indian issues sharpened by the face-off in Chiapas with the Zapatistas, the recognition of the Seris "eland rights through a presidential 
executive order in 1963, passing of the Linguistic Bill of Rights in 2003 and the concomitant creation of the Instituto Nacional de Lenguas Indígenas.

It would be simplistic to say that any single one or any pair of these factors caused the turnaround of the Seri population decline. Perhaps some crucial synergy created by several of them working together was responsible for one improved index and others of them for other indices. But the good news is that the Seri population is something closer to 800 individuals and at this point in time (late 2007) virtually all children with two Seri parents speak Seri as their dominant language. ${ }^{1}$

\section{A period of extended documentation}

Up until the middle of the twentieth century, very little was known about the Seri culture and language. In fact, even to this day there has been no long-term anthropological study of any depth done by trained anthropologists. The published anthropological works have been sometimes large or broad, but they were done with embarrassingly small amount of research time in the field; the results have mostly been superficial and/or seriously flawed. ${ }^{2}$

McGee"s (1898) report to the Smithsonian was the largest and is widely quoted, but it was based on second-hand reports expanded by a six-day visit with the Seris themselves. Despite McGee's later professional achievements, he was not a trained anthropologist. While Kroeber"s training and experience were much more extensive, his (1931) study was written after a visit of a few days. Nolascoes (1967) description compiles data from the previous two studies and is complemented by limited and sometimes erroneously-interpreted observations made during a visit of unspecified length during a two-month period. Malkin (1962) was a general, but limited, ethnozoological study. A later study, Cuéllar 1980, was also done with limited contact and was rather focused on economic aspects of the culture. Felger and Moser"s (1985) ethnobotany, despite being interested primarily in plants, gives by far the best general picture of Seri culture that has been published.

The outside world's knowledge of the language was even more limited, consisting of various short lists of words transcribed with difficulty (given the complexities of pronunciation) which, if anything, correctly showed that the language was challenging. The Moravian Jesuit priest Padre Gilg claimed in 1692 to have written a grammar of the language since he had learned it (Di Peso and Matson 1965: 48), but very unfortunately no trace of this grammar has ever been found.

Interest in the language from the beginning was primarily focused on its relationship with other languages. To what family did it belong? Of course, the earliest speculations were wild and uninformed, which should be of no surprise - it was related to Chinese, Patagonés, Arabic, Carib or Welsh (the latter probably due to the voiceless lateral fricative). Later hypotheses, formulated by linguists Dixon, Kroeber, and Sapir, placed the language within the newly-proposed Hokan stock, which was once linked with Coahuiltecan and even Siouan (both hypotheses long discounted but still occasionally cited by unsuspecting members of the public). But with all of the challenges that existed dealing with endangered

\footnotetext{
1 The website of the government agency Comisión para del Desarrollo Indígena (CDI) (http://www.cdi.gob.mx/index.php?id seccion=660) lists 716 members of the community of whom $72.4 \%$ are said to speak the language. These figures do not seem to be accurate (low in both cases, especially the latter). Another page on the site, http://www.cdi.gob.mx/index.php?id seccion=1447, claims that the same census of 2000 documents 458 speakers. The site inaccurately gives the name ,konkaak ${ }^{\text {ee }}$ as the name of the language; this is a persistent misunderstanding by outsiders. "Comcaac" is the self-designation for the people group, and "cmiique iitom" is the standard expression for the Seri language.

2 The 54 page monograph by Griffen (1959) is the most comprehensive and the most accurate, done by an young anthropologist who spent just over a month in Desemboque for the field research more in 1955.
} 
languages within the U.S. borders, no linguist ventured to Seri country (considered to be much more dangerous in more ways than one), other than Kroeber for a few days in 1930, to collect some data firsthand (Kroeber 1931).

The picture changed drastically with the arrival of a young American couple, SIL members Edward and Mary (Becky) Moser - easterners, to boot - who took up residence with the Seris in 1951 with the intention of learning the language and translating the New Testament. Their linguistic work went in tandem with broad-based humanitarian work that preceded the establishment of government clinics helping with a program giving gamma globulin for measles, with midwifery, dealing with dynamiteinflicted and other wounds, general medical help (including transportation to the nearest hospital eight hours away), helping secure a regular water supply, and other general help. Most importantly, by learning the language and making good application of their basic linguistic training, this couple quickly became in essence the recorders of culture and language data that lasted for many years. The documentation resulted in numerous publications of anthropological and historical interest, drawing solely on direct observations and long interviews with the Seri people conducted in the language itself.

The interest of (primarily American) archaeologists, anthropologists and researchers in other sciences continued to develop during this period and many of them discovered the importance of actually talking to the Seri people and learning from them. Several of the important publications were co-authored with the translator-linguists since the Mosers were an important link in the research. ${ }^{3}$ Year by year the documentation by the Mosers of the minute details of the grammar continued to grow. During a visit to the area by a prominent arid lands botanist, a research program was set into motion that would last more than twenty years and result in the publication of a landmark ethnobotany (Felger and Moser 1985) which drew attention to the fragile cultural treasure that was on the verge of extinction. This book, published in 1985, inspired research in more domains as it helped scientists realize that groups like the Seris were the inheritors of millennia of knowledge and experience that was both valuable and in great danger of being lost.

During this time, the resident translator-linguists continued to record and transcribe legends, stories, conversations, and history. Some were published for the outside world but most were published in the language for the people themselves. These publications tested the writing system that had been developed and refined over the years. Some Seris achieved modest levels of reading ability although reading material was limited. At different times the fledgling and resource-strapped schools attempted to include the Seri language in their curriculum.

Another fact which should not be overlooked: for the translator-linguists, the small adobe home (with no running water and no electricity) in the Seri village was their only home, they spoke the language with the people, and they raised their only child there (who grew up as a native speaker of the language).

\section{A point of crisis and a convergence of interests}

Twenty-five years into their period of residence with the Seris, the Mosers had witnessed many changes. The Seri people had become sedentary town-dwellers on their own government-deeded territory and had traded a mobile hunter-gatherer existence for an economy centered on small-boat commercial fishing and the sale of handcrafts. As time passed, more and more food was purchased rather than procured in the

\footnotetext{
${ }^{3}$ The list of these publications can be found at http://www.ethnologue.com/show author.asp?auth=5402, http://www.ethnologue.com/show_author.asp?auth=5404, and http://lengamer.org/admin/language folders/seri/user uploaded files/links/File/BibliografiaElectronicaSeri.htm.
} 
traditional ways. By the $1960^{\circ e}$ s many of the obvious problems caused by alcoholism had been diminished by the influence of a Mexican church, although issues with illicit drug use began to rise in the 1970"s and the threat from diabetes began to makes itself felt. People had money and could buy their own vehicles, pay for their children to be born in the hospital, and do other things that they wanted. Despite some alarmist reports (Nolasco 1967, Mejido 1976), the Seri culture was not self-destructing and the people were not dying off from mistreatment.

However, not many could read their language well, and no one could write with any real facility. The role of literacy in the community was marginal. Attempts to teach the language in the school were never very successful, both for lack of teachers who spoke the language (they were usually outsiders) and for lack of adequate materials - only a few story booklets and a set of primers existed, all produced by the Mosers. Bilingual language programs have presented great challenges for all governments, and Mexico was no different; the indigenous languages are many and complex, budgets and training are inadequate, and even teachers were often not sympathetic toward literacy in the indigenous languages.

And then Edward Moser died suddenly of a heart attack in 1976. This single event could have brought everything relating to the documentation of the language and culture to an abrupt halt. But it didn't. Within a matter of weeks, Becky Moser was back at work, completing the translation of the New Testament (published in 1982), completing work on the manuscript of the ethnobotany book with botanist Richard Felger (Felger and Moser 1985), editing a contribution for a book on child birthing (Moser 1982), working on the translation of another historical text (Moser 1988), among many other things. Work on producing a full-sized bilingual dictionary from the paper lexical files was also initiated.

It was during this time that other people began to be involved. The author of this article married the Mosers ${ }^{\text {ee }}$ daughter (1976) and began to take an increasing interest in the language. The application of new ideas about the phonology and different ideas about writing led to some modest changes in the spelling system. More of the information about the grammatical structure of the language was laid out. Some of that was published in a booklet, in Spanish, that made the facts accessible to outsiders.

At about the same time, the small linguistics department at the university in the state capital began to show some interest in the language, and the grammatical sketch served as a direct bridge between the linguistics students and the Seri community. A dissertation generally laying out the grammatical structure of the language was completed (Marlett 1981).

Meanwhile, the ethnobotany volume had inspired others to work directly with the Seris on their knowledge of the environment. A steady stream of theses, dissertations and books by American and Mexican scholars on ecology (Rosenberg 1997), fish (Torre 2002), reptiles (Nabhan 2003), and birds (Morales 2006), has appeared. Interest in the ecological and commercial aspects of natural resources such as a certain mollusk (Basurto 2002) has also brought scientists into regular contact with Seri culture. A major ethnography of mollusks is in final stages of preparation (Cathy Marlett).

Some of the projects began to employ Seris as ,paraecólogosee (as they are called in Spanish) and some of the outsider scholars began to expect the Seris to be able to record information in the language, which was difficult for them to do, however. The schools continued to not be very interested in the written language. Literacy had not become very widespread. The New Testament was not used in a very public or obvious way. The traditional stories went out of print. Becky Moser retired and moved away. At that point the documentation could have stopped, the files and recordings archived, and future linguistic research been limited to the peculiar interests of linguistic theory. But since the language was still being learned and used by almost all of the children in the community, and in many domains, that did not seem to be the appropriate action.

During the years 2002-2004 a group of Seris worked with Becky Moser, her daughter (and my wife) Cathy, and me to complete a trilingual dictionary that would pull together fifty years of lexical data 
collection, with the additional support of the U.S. National Science Foundation. This project brought us into a working relationship with some very talented Seri men and women. Most of the men were smallboat fishermen who fit their work on the dictionary between other activities. One of these men, during discussions with the rest of the committee, asked in his characteristically polite way to have his personal way of writing the language reviewed. The symbols were the same; the differences centered on how words were divided, and he showed an uncanny perception of the difference between clitics and affixes. The committee adopted his suggestions. Interaction with another committee member revealed the necessity to use more punctuation than had been previously used. As a result of the years of work on the dictionary (published in late 2005) and all that preceded it, a writing system has resulted that is both very functional as well as aesthetically pleasing. (The major steps in the evolution of the Seri spelling system are documented in Marlett (2006).)

Much of the work on the dictionary was done in full view of the community itself rather than in a distant office. We lived in a pop-up tent trailer that was parked in the middle of one town or the other, and worked out of the small attached screened-in porch. It was not uncommon for four to six of us to be at work in these confined quarters and have various people standing or sitting outside this area to listen to and sometimes comment on the discussion. I remember one night sitting outside in the dark of the screened-in tent working on my laptop and two young boys came by to check out what was happening. Speaking in Seri, they asked about the words that were on the screen and began sounding them out. I believe that this is an important part of the documentation process - to interest the next generation. One of our dictionary consultant team members explicitly remembered as a child watching his grandfather and Ed Moser working in Moser"s small home office and talking about words, and he wondered if he would ever get to do something like that.

The dictionary is itself a miniature cultural display. At more than 900 densely-packed pages, it is large enough and rich enough to give a young Seri person pride in his or her language. Copies were made available to every family courtesy of the National Science Foundation and (with a much greater investment) the Sonoran state government. As one young man said as he received and began to peruse his copy, ,This is like gold to us!e Some began to review the book for information that they didn't know since the book included words and usages collected from elderly speakers half a century earlier. Others began to read the book in order to learn how to write. Others used the paradigms included in the dictionary to impress non-Seris with the complexity and regularity of the language.

Dialect differences are virtually non-existent in the community (although they do exist as remnants from the former clan system) and therefore have not been a major challenge at any point for the development of a standardized writing system. It has also been helpful that the Seris have always had a positive attitude about their own language, due in part because of the social chasm between them and mainstream Mexican culture. They have also had a positive attitude about the writing of the language.

The dictionary is obviously part of the reason for a recent surge of interest by young people in learning to read and write their language. The interest is also undoubtedly encouraged by the increasing expectations of government agencies and non-governmental organizations which expect the Seris to be able to write their language. More work is being done now by another generation of non-Seri botanists who not only record plant names in Latin, but also in Seri, including the location (written in Seri). The Seri contribution to this recent effort is also enhanced by the participation of a Seri man who on his own initiative has learned the Latin names of the plants as well. As this man remarked to me, it was a lifechanging experience for him to see the ethnobotany — despite being written in English — that cataloged so much information about his own culture.

Indications of appreciation like this come informally and sporadically. After one day of working on the dictionary, we were conversing over a meal with the small group about Mexican holidays. We were 
told that the Seris didn't celebrate any of them; obviously those dates and events were of no importance to them. But that evening as we were talking again, one man asked me when the dictionary would be published and then added „I will suggest to the rest of the elders that we designate our first official Seri holiday (apart from the Seri New Year). We should call it something like ,the day to celebrate the coming of the books', because these books - the dictionary, the ethnobotany, and the New Testament — mean so much to us."

During the last few years, there has been a convergence of interests that make documentation of the language of greater importance to the people themselves as well as to the outside world. It is recognized that the language is of considerable interest per se in that it is relatively devoid of obvious borrowings and influence from neighboring languages and Spanish. It provides a window on another way of structuring the world, a tremendous keyhole glimpse into prehispanic Mexico. We now know that it has interesting and unusual properties in many areas of its morphology and syntax, some of which are even just now being appreciated. These include: impersonal passives of transitive verbs (Marlett 1984a), a switchreference system that challenges linguistic theories (Farrell, Marlett and Perlmutter 1991), a stress system that makes reference to root boundaries as well as syllable weight (Marlett, in press d), kinship verbs (Evans 2000), denominal verbs (Marlett, in press c), perhaps the most extensive set of kinship terms ever recorded (Marlett and Moser 1989), articles used with names (Marlett 2008, Anderson 2007), internallyheaded relative clauses with embedded determiner phrases, number verbs as raising predicates (Marlett 1984b), positional demonstratives derived from deverbal nouns, and emerging noun class systems (Marlett and Moser 1994). More studies continue to center on a knowledge of the Seri view of their world (Luque and Doode 2003, Luque and Robles Torres 2006) and these studies appreciate the Seri expression of these beliefs.

Through the establishment of INALI (Instituto Nacional de Lenguas Indígenas), the government of Mexico, is taking greater steps and committing more resources to strengthen the vitality of the indigenous languages. Each of these steps, as well as the efforts of the CDI (Comisión Nacional para el Desarrollo de los Pueblos Indígenas) (the successor of the INI), affirm to the Seris the value of their language and their culture.

Some of the Seris who contributed to the dictionary are today (with outside encouragement) beginning to write monolingual pieces — short and long — about different aspects of their culture and history. These are being made available and archived in written, audio and sometimes video versions (AILLA, Archive of Indigenous Languages of Latin America, Austin, Texas). Two of the people crucially involved in writing these materials are known within the community as belonging to the lineage of the hant iiha cöhacomxoj, the informed ones " who have the responsibility to transmit knowledge. In previous generations, this was done only orally, of course, but today it is recognized that written documents, audio recordings and video are essential as well. We have already been able to tap into some of the recordings of folklore and history made forty years ago by the Mosers. Some people are listening to their grandfather or great-grandfather recounting things they have never heard. The documentation of a previous generation is being brought home in numerous ways.

This material, moreover, is beginning to provide the nucleus of reading material for the schooling system that has heretofore been disinterested in or unable to deliver any competency in reading and writing the minority language.

The formal documentation of the language has meant paying attention to the minutiae of the language - including the little words that have presented the greatest challenges to the writing system. This work has provoked long discussions with key Seri consultants who do not endure these discussions but rather seem to thrive on them. 
The same people involved in the final stages of the lexicographic work are also working today on finalizing a major grammatical description and a corpus of traditional texts through work sponsored by the Documenting Endangered Languages program of the National Endowment for the Humanities and the National Science Foundation (see Marlett 2007b). Through those projects and through their own writing (see Montaño Herrera et al 2007), they are being exposed again to the challenges of writing, grammar and style. They are becoming major consultants for the next phase of bringing this work to fruition, which is to prepare a generation of Seris for whom reading and writing are an integral part of life.

\section{Challenges for the next fifty years}

The challenges for the next fifty years for the Seri people are no less great, although they different, from those during the past five centuries. There is no turning back the clock. The forces that press on them will not be avoided unless the people were to once again flee into the mountains and abandon almost everything they have known during the past century.

The effect of globalization on the Seri culture has been as steady as it has been unavoidable. One of the Seri men who helped work on the dictionary was living in a house with temporary pressed-board walls and a dirt floor; but he had a color television. One night after working on the dictionary I was talking to him about some music that we especially enjoyed that was performed by an Italian tenor who happened to be blind. Without batting an eye, he replied, „Oh, do you mean Andrea Bocelli? ${ }^{e e}$ A Mexican television company contracted to have Seri music sung on their network, and as a result of that, one Seri man was given a short gig in one of the large casinos in Las Vegas, Nevada. People who are promoting ecology take Seri young people to New York City. Other parties take them to cultural events in Paris.

The effect of these occasional events on the Seri worldview and on the use of their language is unclear. The most pervasive, and certainly most tendentious, influences are much closer to home and even in the home itself. Some of the Seri young people who go to schools outside of the Seri villages come back with the idea that if they really want to advance economically they will have to give up their culture. Some suggest allowing hotel chains or land developers to come in and occupy their territory. One young man came back and put a gun to his head and pulled the trigger, from despondency about racial purity after reading Mein Kampf in a non-Seri school. Economic prosperity has brought electricity and television, including satellite programming. Children and women spend less time in the real world and more time in the artificial world of soap operas taking place in a world that becomes less and less foreign to them. Schooling is still primarily based on a Spanish-language curriculum. Economic activity of buying and selling brings non-Seris on a regular (but limited) basis into the Seri community.

One aspect of the local context is, at this point, relatively neutral. The local church activities are conducted primarily in the Seri language, although one may detect a drift toward Spanish as the leaders try to be accommodating to the non-Seri congregants. This is also one port of entry for greater influence from Spanish-speakers to operate directly in the community since traveling Spanish-speaking evangelists are frequent visitors.

In some respects, the groundwork for language documentation has just been laid now that some Seris are able to write well and are beginning to teach others. Is there a critical mass to make this selfsustaining? Not yet. Are there people who will carry on writing and documenting their language and culture without being hired by outsiders to do so? There may be one such person. The bright side of this is that this person is unusually gifted in writing, respected by young and old alike, and is at the same time deeply rooted in traditional culture. A current goal is to see a shift from reliance on outside initiatives and outside resources that have up to now been the means of doing any of this. It would be unfortunate if the 
past decades have taught the Seri people that they can or should do something only at the suggestion of an outsider and with a salary paid by the same.

The documentation of the language and the application of that knowledge to the local community have made it possible for the Seris themselves to participate in the documentation of their heritage. Their successful writing of the language shows the importance of using the practical writing system so that the community is a participant in the documentation.

The current project has resulted in essays that have brought to light exquisitely beautiful parts of the culture that have never been documented before (Moreno Herrera, to appear; Herrera Casanova, to appear; Montaño Herrera, to appear). These essays have also revealed parts of Seri oral history that have never been discussed with outsiders in any detail and certainly never published. The written language has given a new voice to the previously only oral passing of traditions and values.

A goal of the current period is to strengthen the use of the Seri language - including the written language - in every sphere of Seri life — in the schools (more materials at various levels, more training for teachers), in the so-called traditional schools (more appreciation for the wide range of topics to be included, production of materials), in the home (personal albums, journals, records), in the church, and in the places of commerce.

\section{References}

Anderson, John. 2007. The grammar of names. Oxford and New York: Oxford University Press. Basurto, Xavier. 2002. Community-based conservation of the callo de hacha fishery by the Comcáac Indians, Sonora, Mexico. Master of Science thesis, University of Arizona, Tucson.

Bowen, Thomas. 1983. Seri. Handbook of North American Indians, ed. by William C. Sturtevant. Southwest, ed. by Alfonso Ortiz, 230-249. Washington, D.C.: Smithsonian Institution.

Campbell, Lyle. 1997. American Indian languages: The historical linguistics of Native America. Oxford and New York: Oxford University Press.

Coolidge, Dane and Mary Roberts Coolidge. 1939. The last of the Seris. New York: E. P. Dutton.

Corey, Herbert. 1922. Adventuring down the west coast of Mexico. The National Geographic Magazine 42.5: 449-503.

Cuéllar, José Arturo. 1980. La comunidad primitiva y las políticas de desarrollo: el caso seri. Mexico City: UNAM.

Di Peso, Charles C. and Daniel S. Matson. 1965. The Seri Indians in 1692 as described by Adamo Gilg, S.J. Arizona and the West 7: 33-56.

Evans, Nicholas. 2000. Kinship verbs. Approaches to the typology of word classes, ed. by Petra M. Vogel and Bernard Comrie, 103-172. Berlin and New York: Mouton de Gruyter.

Farrell, Patrick; Stephen A. Marlett, and David M. Perlmutter. 1991. Notions of subjecthood and switch reference: evidence from Seri. Linguistic Inquiry 22, 431-56.

Felger, Richard and Mary B. Moser. 1985. People of the desert and sea: ethnobotany of the Seri Indians. Tucson: University of Arizona Press.

Griffen, William B. 1959. Notes on the Seri Indian culture, Sonora, Mexico. Gainesville: University of Florida Press.

Herrera Casanova, Lorenzo. To appear. Those who had Hast Quita as their birthplace. Inside dazzling mountains, ed. by David Kozak. Lincoln: University of Nebraska Press.

Herrera Moreno, Francisco Xavier. To appear. Twin Peaks - Hast Cacöla. In Inside dazzling mountains, ed. by David Kozak. Lincoln: University of Nebraska Press.

Kroeber, A[1fred] L. 1931. The Seri. Southwest Museum Papers 6. 
Luque A., Diana and Gabriela H. Doode. 2003. Des-cubriendo .... el orden, la naturaleza y el territorio comcáac. Gaceta Ecológica No. 068: 23-32. Mexico City: Instituto Nacional de Ecología.

Luque Agraz, Diana and Antonio Robles Torres. 2006. Naturalezas, saberes y territorios comcáac (seri): diversidad cultural y sustentabilidad ambiental. Mexico City and Hermosillo: Secretaría de Medio Ambiente y Recursos Naturales, Instituto Nacional de Ecología, y Centro de Investigación en Alimentación y Desarrollo.

Malkin, Borys. 1962. Seri ethnozoology. Pocatello, Idaho: Occasional Papers of the Idaho State College Museum 7.

Marlett, Cathy Moser. In preparation. Seri ethnology of mollusks.

Marlett, Stephen A. 1981. The Structure of Seri. Dissertation, University of California at San Diego.

Marlett, Stephen A. 1984a. Personal and impersonal passives in Seri. Studies in relational grammar 2, ed. by David M. Perlmutter and Carol Rosen, 217-239. Chicago: University of Chicago Press.

Marlett, Stephen A. 1984b. Switch-reference and subject raising in Seri. Syntax and semantics 16: the syntax of Native American Languages, ed. by E.-D. Cook and D. Gerdts, pp. 247-68. New York: Academic Press.

Marlett, Stephen A. 2006. La evolución del alfabeto seri. Octavo Encuentro Internacional de Lingüística en el Noroeste, vol. 3: 311-329. Hermosillo: Universidad de Sonora.

Marlett, Stephen A. 2007a. Loanwords in Seri: the data. Draft available online: http://lengamer.org/admin/language_folders/seri/user_uploaded_files/links/File/Loanwords_in_Se ri.pdf.

Marlett, Stephen A. (compiler). 2007b. Ziix haptc iiha comcaac quih ocoaaj quih ano yaii. (Acervo de textos seris). Online: http://www.lengamer.org/admin/language_folders/seri/user_uploaded_files/links/File/Acervo_de Textos/acervo de textos.htm.

Marlett, Stephen A. 2007c. Bringing it home: the implications of documentation for a vibrant endangered language. Proceedings of conference on language documentation and linguistic theory, eds. Peter K. Austin, Oliver Bond and David Nathan, pp. 157-163. London: School of Oriental and African Studies, University of London.

Marlett, Stephen A. 2008. The form and use of names in Seri. International Journal of American Linguistics 74.1: 47-82.

Marlett, Stephen A. In press a. La relación entre las lenguas "hokanas" en México: ¿Cuál es la evidencia? (Paper presented at the Tercera Conferencia Swadesh. UNAM, México, D.F.)

Marlett, Stephen A. In press b. The Seri and Salinan connection revisited. International Journal of American Linguistics.

Marlett, Stephen A. In press c. Denominal verbs in Seri. International Journal of American Linguistics.

Marlett, Stephen A. In press d. Stress, extrametricality and the minimal word in Seri. Linguistic Discovery.

Marlett, Stephen A. and Mary B. Moser. 1989. Terminología de parentesco seri. Anales de Antropología 26: 367-88. Mexico City: UNAM.

Marlett, Stephen A. and Mary B. Moser. 1994. El desarrollo de clases nominales en seri. Estudios de Lingüística y Sociolingüística, eds. Gerardo López Cruz and José Luis Moctezuma Zamarrón, pp. 97-103. Hermosillo: Universidad de Sonora and Instituto Nacional de Antropología e Historia.

McGee, W. J. 1898. The Seri Indians: Seventeenth annual report of the Bureau of American Ethnology to the Secretary of the Smithsonian Institution. Washington, D.C.

Mejido, Manuel. 1976. México amargo. (Pp. 75-77, Los seris mueren entre mar, vicio y desierto.) México, D.F.: Siglo Veintiuno. 
Montaño Herrera, René. To appear. Leatherback sea turtle — xiica cmotomanoj. Inside dazzling mountains, ed. by David Kozak. Lincoln: University of Nebraska Press.

Montaño Herrera, René; Francisco Xavier Moreno Herrera, and Stephen A. Marlett, eds. Comcaac quih ziix quih ocoaaj hac (Enciclopedia seri). Online: http://lengamer.org/admin/language folders/seri/user_uploaded files/links/File/Enciclopedia/Enci cloSeri.htm.

Morales Vera, Thor. 2006. Las aves de los comcáac (Sonora, México). Thesis for licenciatura. Jalapa: Universidad Veracruzana.

Moser, Mary B. 1982. Seri: from conception through infancy. Anthropology of human birth, ed. byMargarita A. Kay, 221-232. Philadelphia: F.A. Davis.

Moser, Mary B. 1988. Seri history (1904): two documents. Journal of the Southwest 30: 469-501.

Moser, Mary B. 1996. Seri de Sonora. Archivo de lenguas indígenas de México. Mexico City: El Colegio de México.

Moser, Mary B. and Stephen A. Marlett, compilers. 2005. Comcáac quih yaza quih hant ihiip hac: Diccionario seri- español-inglés. Mexico City and Hermosillo: Plaza y Valdés Editores and Universidad de Sonora.

Nabhan, Gary P. 2003. Singing the turtles to sea: The Comcáac (Seri) art and science of reptiles. Los Angeles: University of California Press.

Nolasco, Margarita. 1967, Los seris, desierto y mar. Anales, Instituto Nacional de Antropología e Historia 18: 125-194. Mexico Ctiy.

Rosenberg, Janice. 1997. Documenting and revitalizing traditional ecological knowledge: The curriculum development component of the Seri ethnozoology education project. M.A. thesis, University of Arizona, Tucson.

Sheridan, Thomas E. 1979. Cross or arrow? The breakdown in Spanish-Seri relations 1729-1750. Arizona and the West 21:317-34.

Sheridan, Thomas E. 1999. Empire of sand: The Seri Indians and the struggle for Spanish Sonora, 16451803. Tucson: University of Arizona Press.

Spicer, Edward H. 1962. Cycles of conquest: the impact of Spain, Mexico, and the United States on the Indians of the Southwest, 1533-1960. Tucson: University of Arizona Press.

Torre Cosio, Jorge. 2002. Inventory monitoring and impact assessment of marine biodiversity in the Seri Indian territory, Gulf of California, Mexico. PhD dissertation, University of Arizona, Tucson. 